\title{
Editorial
}

\section{Back to the humanities}

This issue of Leadership and the Humanities showcases the diverse approaches and disciplines that contribute to a humanities perspective on leadership. Taken together, they help frame an understanding of leadership that is informed by culture and history, politics and institutional structure, and philosophy and ethics.

In our opening piece, management scholar Jeffrey McClellan (Frostburg State University) explores how leadership played out in precolonial Ecuador, before the arrival of the Inca and the Spanish. McClellan proposes a model of indigenous leadership in Ecuador based in part on an analysis of the different sources of power available to precolonial indigenous leaders, including kinship and paternal heritage, economic networks and wealth, religion, and military strength. McClellan compares this framework of leader power to the pattern subsequently imposed on Ecuador by the Inca and then during the colonial era by Spanish rulers. His analysis grants significant influence to these external conquerors, but also notes the survival of 'leadership cultural paradigms' that endure today. Modern Ecuador, McClellan argues, 'is unique in the combination of its relative diversity of indigenous groups and the level of indigenous involvement in politics.' One key lesson of McClellan's study - especially important for leadership scholars exploring contemporary leadership situations - is to emphasize the enduring impact of culture and cultural identity on subsequent expectations about what leadership is expected to look like, what 'normal' leadership feels like in a particular society. McClellan, drawing broadly on the work of Edgar Schein (1992), Geert Hofstede (1980), and Robert House et al. (2004), reminds us that culture and history are fundamental shaping forces for making sense of leadership.

In our second piece, Steven Dandaneau, Vice Provost for Undergraduate Studies and a sociology professor at Kansas State University, explores the "precarious experiments' of American land-grant colleges and universities through a study of the life and work of Milton S. Eisenhower, who led three universities - Kansas State, Penn State, and Johns Hopkins - over most of three decades, from 1943 to 1972. Dandaneau examines Eisenhower's leadership through the prism of land-grant institutions of higher learning, created by the Morrill Act of 1862. The Morrill Act, signed by President Abraham Lincoln, set forth an aspiration for colleges to serve as democratic - and democracy-building - learning institutions, an aspiration that exists in tension with the role that college education plays in reinforcing class-based socioeconomic distinctions and divisions. Dandaneau frames his careful historical study of Eisenhower's leadership in a contemporary, post-2008 recession context of the land-grants historically the 'people's colleges,' as Ruby Green Smith (2013) calls them - occupying an increasingly precarious position: Dandaneau envisions a possible future where such institutions transform 'into land-grant universities in name only, having had no choice but to leave behind "the people" in favor of the paying customer.'

In our final piece, Christopher Newport professor Nathan Harter steps back and explores, from the perspective of philosophy, how leaders can 'gain a more authentic 
self-concept.' Starting from the traditional foundational injunction, 'Know thyself,' Harter unwinds a reflective thread that questions the essential nature of the self and considers the ways philosophers from Socrates to Ortega y Gasset and other moderns have thought about the construction of images of the self. Harter proposes three imagined interpersonal perspectives: Plato's ring of Gyges, which bestows invisibility on its wearer, as an instance of 'being no one'; Kant's universalizing categorical imperative as a manifestation of 'being everyone'; and John Rawls's (1971) 'veil of ignorance' as an instance of 'being anyone.' Each of these perspectives, Harter argues in his elegant synthesis, serves to encourage or compel a philosophically minded leader an individual seeking 'a more authentic self-concept' - to 'drop his or her identification with the position of leader,' and, beyond that, 'to drop other, more intimate features of identity.' The proper education of a leader, Harter argues, as suggested by the western philosophical tradition he surveys and compresses, is to help the leader learn his or her true nature by exploring and imagining the natures and identities of others. Philosophy, in Harter's telling, emerges as a hybrid of intellectual, imaginative, and empathetic understanding, which helps leaders better understand their nature, their task, and their connection to others.

These three pieces, from different disciplinary backgrounds, suggest a truth about leadership: it is embedded in contexts, and to study it divorced from these contexts is an arid undertaking. Those contexts - be they history and culture, politics and institutional/bureaucratic settings, or philosophical exploration of human identity and existence - are vital to making sense of the nature of leadership. In my own teaching, I never teach leadership in isolation, but always in the context of the communities leaders are tied to, and serve - and also in the context of culture, bureaucracy, and ethics. Leadership is simply one way that groups and communities seek to organize and guide their activities, their collaborative endeavors: culture and, for modern organizations, bureaucracy are the two other chief 'coordination mechanisms' groups rely on. This Weberian insight situates leadership not in isolation, but in tension, with the other forces that shape the life and work of groups and communities. Leadership, culture, and bureaucracy - along with the choices, actions, and interactions of the individual members of groups and communities - are best studied and explored in complex, messy combination. Such a commitment to the study of leadership leads one to cross disciplinary boundaries, to study history and culture, politics and sociology and economics, literature and philosophy, as keys to making sense of leadership. Such a commitment leads the student of leadership back, ineluctably and persistently, to the humanities.

Michael Harvey 


\section{REFERENCES}

Hofstede, G.H. (1980), 'Motivation, Leadership and Organization: Do American Theories Apply Abroad?' Organizational Dynamics, 9(1), 42-63.

House, R.J., P.J. Hanges, M. Javidan, P. Dorfman, and V. Gupta (2004), Culture, Leadership, and Organizations: The GLOBE Study of 62 Societies, Thousand Oaks, CA: Sage.

Rawls, J. (1971), A Theory of Justice, Cambridge, MA: Belknap Press.

Schein, E.H. (1992), Organizational Culture and Leadership, 2nd edn, San Francisco: Jossey Bass.

Smith, R.G. (2013), The People's Colleges: A History of the New York State Extension Service in Cornell University and the State, 1876-1948, Cornell, NY: Cornell University Press. 